\title{
Is money going digital? An alternative perspective on the current hype
}

\author{
Daniel Gersten Reiss
}

\section{Correspondence:}

daniel.reiss@bcb.gov.br

Central Bank of Brazil, Department

of Banking Operations and

Payments System's Research

Division, SBS quadra 3, Bloco B,

Edificio-Sede, 15 andar, Brasilia, DF

70074-900, Brazil

\begin{abstract}
Current financial discourse suggests the imminence of a cashless society, a concept that arose from the global popularization of digital financial services and the development of technologies with the potential for application in financial markets. However, claims about the impending obsolescence of paper money are neither disruptive nor a novelty. Instead, this paper argues that the conversion of money from paper to bits has been a gradual, adaptive process, and that money is already digital. Moreover, in this paper we propose that the statuses of electronic money (e-money) and banknotes have switched in the view of monetary authorities.
\end{abstract}

Keywords: Digital money, Digital currency, E-money, Digital financial services

JEL classification: $\mathrm{O} 3, \mathrm{~L} 8, \mathrm{G} 21$, E5

\section{Introduction}

Current discourse about money mainly focuses on its supply in a digital format. The wide access to technological products and the introduction of bitcoin triggered recent hype, which suggests that a disruptive transformation in financial markets and systems is imminent. However, corresponding discussions surrounding electronic money (e-money), virtual currencies, digital financial services, and mobile wallets topics commonly overlap with the discussion of the digitalization of money.

Policymakers and regulators have invested considerable effort in dealing with these mixed perspectives on the digitalization of money and catching up with market trends. In addition to hosting discussions at the national level, international bodies have undertaken several initiatives to explore these topics (CPMI 2015; CPMI 2017; IOSCO 2017; Pearlman 2017). Building on the existing literature, we analyze current perceptions of the digitalization of paper money and posit that, despite the recent hype, this digitalization is a long-term, ongoing process.

\section{The rise of digital financial services}

For the most part, what we understand as money is that it stores a quantifiable value that one expects to be traded for any other asset in the short or long run. In our minds, money usually takes the form of sovereign currencies, which are associated with physical money-that is, banknotes and coins (cash).

(c) The Author(s). 2018 Open Access This article is distributed under the terms of the Creative Commons Attribution 4.0 International License (http://creativecommons.org/licenses/by/4.0/), which permits unrestricted use, distribution, and reproduction in any medium, provided you give appropriate credit to the original author(s) and the source, provide a link to the Creative Commons license, and indicate if changes were made. 
Digital financial services have brought financial services from bank branches to our homes and pockets. Thanks to the information and communications technology (ICT) revolution, money can conveniently be transferred from a bank account to an individual from a mobile device. Money transfers (even cross-border), bill payments, and loan requests have all become readily available through technology, bolstering the notion that money will soon go digital and paper money will become defunct.

However, this concept is neither new nor recent. Although currently presented as disruptive, digital innovations in financial services have been discussed for at least two decades. In the late 1990s, it was already suggested that electronic cash cards could eventually displace cash $^{1}$ (Shy and Tarkka 1998). By that time, both consumers and the industry were enthusiastic about the potential adoption of payment cards, but the economic rationale for the adoption of e-money ${ }^{2}$ remained unclear (Santomero and Seater 1996). Despite their substantial potential benefits, new technologies in the payments market have typically only been adopted after a considerable delay (Berger et al. 1996).

\section{The role of telecommunications in financial inclusion initiatives}

This transformation process occurs both in developed and developing financial markets, even though the two markets are split in the provision of financial services through digital media. In developed markets, next-generation cell phones and wide broadband access have enabled the rise of powerful payment platforms that have allowed the digitalization of traditional services and the launch of innovative products. In these markets, the main concern has been the availability and credibility of innovative products (Dahlberg et al. 2015).

Innovative platforms are booming with novel technologies in developed markets, but access to novel technologies remains limited in emerging markets. In spite of this, the use of e-money has increased in these markets with the help of telecommunications infrastructure. In these markets, the financial inclusion argument is the key driver; instead of new technologies, new methods of providing financial services supported by e-money have been adopted. Since mobile services have gained more widespread adoption than financial services among poorer segments of the population, financial inclusion initiatives are heavily dependent on the telecommunications network infrastructure (Albuquerque et al. 2014).

Figure 1 illustrates the considerable extent to which financial inclusion is dependent on telecom coverage in developing countries. When we observed the averages of various countries' telecom coverage, we observed that the gap between financial services accessibility and telecom accessibility was considerably lower in developed countries (right panel) than in developing countries (left). Similarly, as telecom infrastructure was increasingly relied on for e-money transfers, the use of cell phones for making small payments rose in some African countries (e.g., Kenya and Tanzania) and was adopted as a major financial inclusion policy in Latin America countries such as Peru. ${ }^{3}$

E-money has flourished as a representation of national currencies. Consisting of smart cards and internet-based solutions such as PayPal, e-money and digital wallets have kept pace with traditional money storage solutions in developed markets. In developing markets, by contrast, e-money and digital wallets have emerged as the core financial solution for the previously unbanked. ${ }^{4}$ 


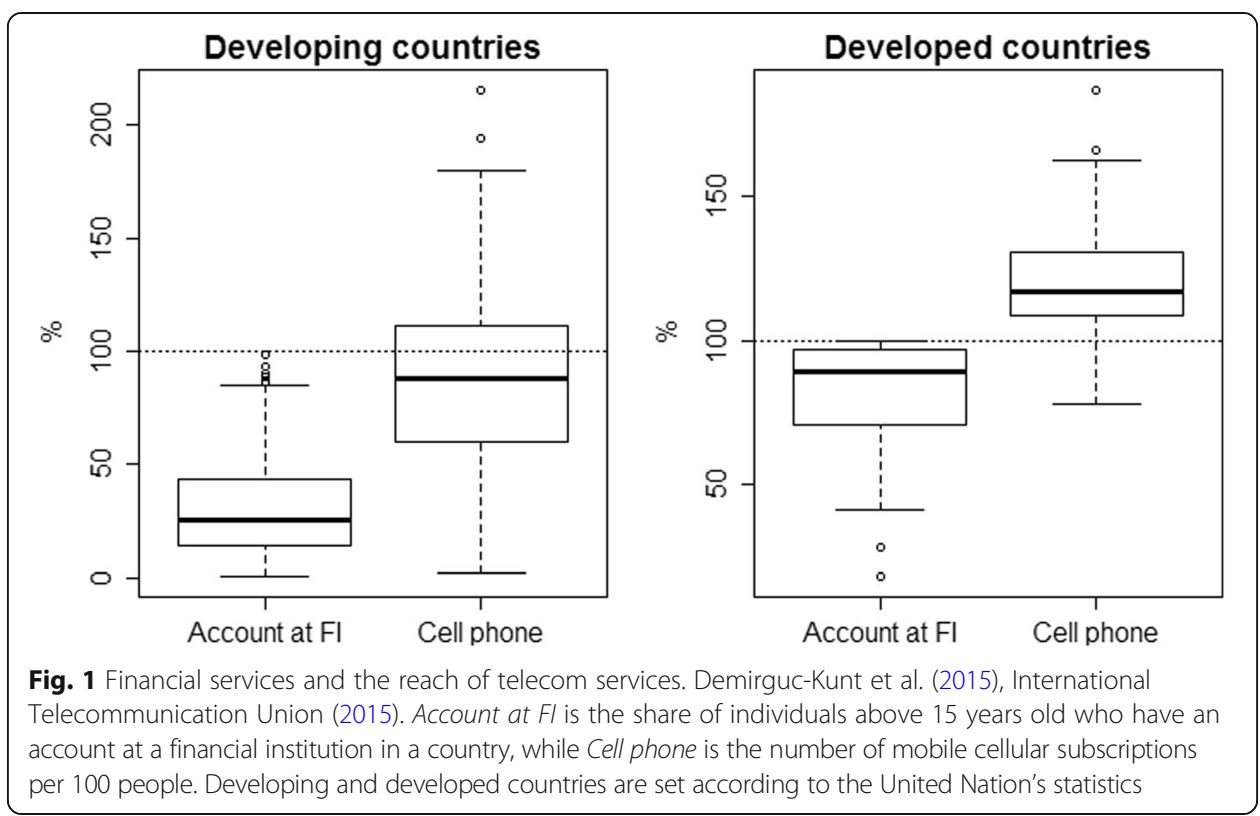

\section{The most usual form of money}

However, e-money is not the only digital form of money. In fact, bank accounts have been digitalized since banks records were first transformed from accounting books to computer systems. Even though cash is a high-turnover commodity commonly used by people for retail payments, most money is stored in digital form. Figure 2 displays the series ratio of cash in circulation outside banks to broad money for selected countries from 2006 to 2015. Cash in circulation can be defined as the money in peoples' hands

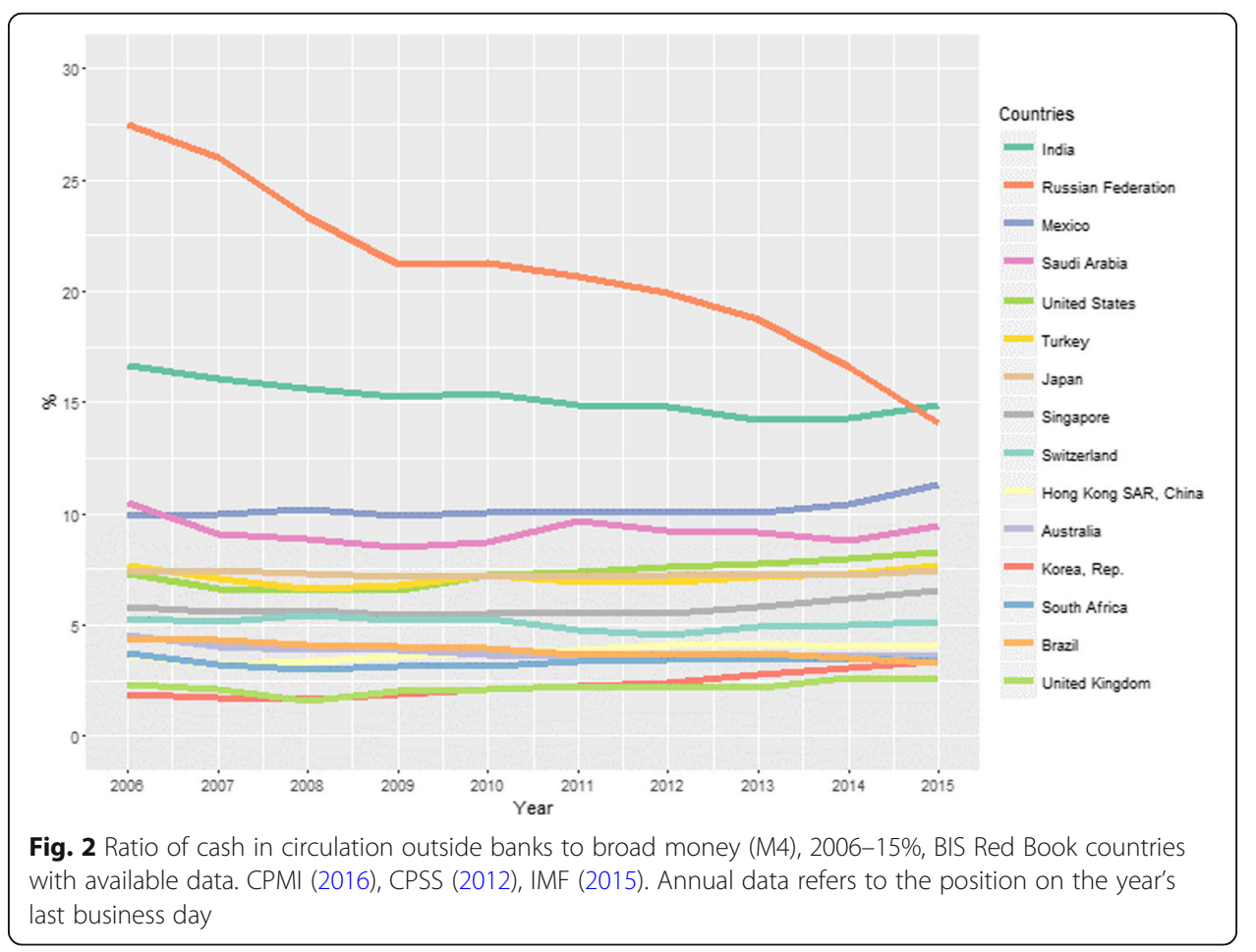


that is used for trade or savings. When individuals stored their cash in banks, it transformed, in their view, into a digital form. In addition to cash in circulation, broad money includes digitally represented money (e.g., demand deposits, e-money, and money in savings accounts). The country series correspond to the available data from countries reported in the BIS Red Book (CPMI 2016; CPSS 2012).

The 2015 figures show that India and Russia were the countries with the largest ratio of cash in circulation outside banks to broad money, at 15\%. Russia demonstrated a sharp reduction in its ratio, of almost $30 \%$ in 2006, whereas India showed a slightly downward trend. All other countries fell below the 10\% ratio, with the ratio below 5\% in the United Kingdom, Brazil, South Africa, and Korea. However, cash in proportion to the whole economy remained somewhat stable during the past decade in these countries. No relevant changes were observed in the other countries except for Mexico and Korea, where there was a slight increase. The most of the existing money in the surveyed countries was already in digital form.

Roughly just $10 \%$ of the global money supply is still not digital. Some reasons people continue to hold cash $\operatorname{are}^{5}$ : (i) its potential use as a medium of exchange when no other electronic payment methods are accepted by the counterpart agent; (ii) the protection it offers against financial institutions (cash is a liability against the currency issuer, whereas all other forms of money are liabilities against other financial intermediaries, and cash is a trusted paper representation of monetary value because the central bank is a trusted certifier of the currency), and (iii) the privacy it affords in financial transactions. The analysis of the motives for behaviors (ii) and (iii) are beyond the scope of the present note. Two current discussions cover these issues: motive (ii) in the central bank digital currency $(\mathrm{CBDC})$ context and motive (iii) in the cryptocurrency context. ${ }^{6}$

\section{The future for cash}

Since online transactions are a requirement for payment transactions, ${ }^{7}$ the availability of electronic currency that can replace cash-motive (i)-is dependent on the cost of telecommunications infrastructure. As evidenced in remote areas without widespread and reliable telecom infrastructure, e-money is not always a less expensive replacement for cash. We expect, however, that such examples will become increasingly rare as ICT advances and the cost of telecom infrastructure decreases. Consequently, the use of cash will gradually become restricted to increasingly smaller niches.

As the use of cash declines, it may become inefficient for a central bank to continue to administer its logistics. This idea reiterates the notion that the issuers of e-money are private institutions making tokens from money in circulation. In reality, the opposite behavior appears imminent) - that is, 130 monetary authorities will distribute digital money while private institutions will make paper tokens from it as a niche service. ${ }^{8}$

\section{Conclusion}

E-money may be granted a higher status than cash as ICT advances. Nonetheless, money, as a representative form of a quantifiable and tradable value, has transformed from a physical representation of bullion to a digital record kept at trusted institutions. During this transformation, e-money has become more convenient and has reached a broader group of users. Money is already digital. 


\section{Endnotes}

${ }^{1}$ Going beyond the direct relationship between the cash substitution by new digital instruments, discussions on cashless societies go back to earlier times. See, e.g., the discussion between White (1984a, 1986) and Greenfield and Yeager (1986) for a debate on the increasing liquidity of bank deposits.

${ }^{2}$ Typically, jurisdictions define e-money as some monetary value stored on devices or electronic systems, which allows users to make payment transactions. In addition to banks, non-financial institutions, such as card or mobile networks, can usually also issue e-money. For a contrast among different kinds of money, see CPMI (2015).

${ }^{3}$ For country examples, see Jack and Suri (2014), Mas and Morawczynski (2009), and Bernal (2017).

${ }^{4}$ For a more precise discussion on this definition, see CPMI Digital Currencies report (CPMI 2015).

${ }^{5}$ Note that the usual discussed motives for holding cash, such as the precautionary and speculativemotives, are discussed in a context that includes cash and quasi cash holdings (including demand-deposit balances and certificates of deposit).

${ }^{6}$ For CBDC, see CPMI and MC (2018). For privacy in cryptocurrencies, see Androulaki et al. (2013).

${ }^{7}$ The infrastructure resilience also conditions the availability of electronic payment instruments, which is also subject to random shocks such as natural disasters or malicious attacks.

${ }^{8}$ Indeed, this occurrence would be akin to historical systems, where banks issued redeemable claims for outside money (i.e., gold, silver, bronze, etc.). See, e.g., White (1984b), Selgin (1988), Dowd (2002).

\section{Abbreviations}

BIS: Bank for International Settlements; CBDC: Central bank digital currency; CPMI: Committee on Payments and Market Infrastructures; ICT: Information and communications technology; IMF: International Monetary Fund; ITU: International Telecommunications Union

\section{Acknowledgements}

The author is grateful to the anonymous referees for their useful suggestions.

Funding

This research received no specific grant from any funding agency in the public, commercial, or not-for-profit sectors.

\section{Availability of data and materials}

The dataset supporting the conclusions of this article are available in the sources' repositories. For the share of persons above 15 years old that have an account at a financial institution in a country, see World Bank's Financial Inclusion Data / Global Findex at http://datatopics.worldbank.org/financialinclusion/; for the number of mobile cellular subscriptions per 100 people, see ITU's World Telecommunication/ICT Development Report https://www.itu.int/en/ITU-D/Statistics/ Pages/stat/default.aspx; for cash in circulation outside banks and broad money series, see CPMI's Red Book statistics at https://www.bis.org/statistics/payment_stats.htm.

Authors' contributions

The author read and approved the final manuscript.

Authors' information

The views expressed herein are of my own and do not necessarily represent those of the Central Bank of Brazil.

Competing interests

The author declares that he has no competing interests.

Publisher's Note

Springer Nature remains neutral with regard to jurisdictional claims in published maps and institutional affiliations. 
Received: 24 July 2017 Accepted: 4 June 2018

Published online: 06 July 2018

\section{References}

Albuquerque JP, Diniz EH, Cernev AK (2014) Mobile payments: a scoping study of the literature and issues for future research. Inf Dev. https://doi.org/10.1177/0266666914557338

Androulaki E et al (2013) Evaluating user privacy in Bitcoin. In: Sadeghi AR (ed) Financial Cryptography and Data Security. Lecture notes in computer science, vol 7859. Springer, Berlin

Berger AN, Hancock D, Marquardt JC (1996) A framework for analyzing efficiency, risks, costs, and innovations in the payments system. J Money Credit Bank 28(4):696-732. https://doi.org/10.2307/2077917

Bernal MV (2017) Retail payments innovations in Peru: Modelo Peru and financial inclusion. J Paym Strateg Syst 10(4):343-351

CPMI (2015). Digital currencies. Technical report 137, Bank for International Settlements. Committee on payments and market infrastructures. http://www.bis.org/cpmi/publ/d137.pdf. Accessed 01 Jan 2018

CPMI (2016). Statistics on payment, clearing and settlement systems in the CPMI countries - Figures for 2015. Technical report, Bank for International Settlements. Committee on Payments and Market Infrastructures. http://www.bis.org/ cpmi/publ/d152.htm. Accessed 01 Jan 2018

CPMI (2017). Distributed ledger technology in payment, clearing and settlement: an analytical Framework Technical report, Bank for International Settlements. Committee on Payments and Market Infrastructures. Available at https:// www.bis.org/cpmi/publ/d157.pdf. Accessed 01 Jan 2018

CPMI and MC (2018). Central Bank digital currencies. Technical report, Bank for International Settlements. Committee on Payments and Market Infrastructures and Markets Committee. https://www.bis.org/cpmi/publ/d174.pdf. Accessed 01 Jan 2018

CPSS (2012). Statistics on payment, clearing and settlement systems in the CPSS countries - Figures for 2010. Technical report, Bank of International Settlements. Committee on Payment and Settlement Systems. http://www.bis.org/ cpmi/publ/d99.htm. Accessed 01 Jan 2018

Dahlberg T, Guo J, Ondrus J (2015) A critical review of mobile payment research. Electron Commer Res Appl 14(5):265284. https://doi.org/10.1016/j.elerap.2015.07.006

Demirguc-Kunt A, Klapper LF, Singer D and Van Oudheusden P (2015). Global Financial Inclusion Database International Monetary Fund.

Greenfield RL, Yeager LB (1986) Competitive payments systems: comment. Am Econ Rev 76(4):848-849

IMF (2015). International Financial Statistics. Available at http://data.imf.org/

International Telecommunication Union (2015). World Telecommunication/ICT Development Report and Database.

IOSCO (2017). Research Report on Financial Technologies (Fintech). Technical report, International Organization of Securities Commissions. https://www.iosco.org/library/pubdocs/pdf/IOSCOPD554.pdf. Accessed 01 Jan 2018.

Jack W, Suri T (2014) Risk sharing and transactions costs: evidence from Kenya's mobile money revolution. Am Econ Rev 104(1):183-223

Mas I, Morawczynski O (2009) Designing mobile money services Lessons from M-PESA. Innovations: Technology, Governance, Globalization 4(2):77-91. https://doi.org/10.1162/itgg.2009.4.2.77

Pearlman, Leon (2017). Distributed Ledger Technologies and Financial Inclusion. Technical report, International Telecommunications Union. http://www.itu.int/en/ITU-T/focusgroups/dfs/Documents/201703/ITU_FGDFS_Reporton-DLT-and-Financial-Inclusion.pdf. Accessed 01 Jan 2018.

Santomero AM, Seater JJ (1996) Alternative monies and the demand for Media of Exchange. J Money Credit Bank 28(4): 942-960. https://doi.org/10.2307/2077930

Selgin GA (1988) The theory of free banking: money supply under competitive note issue. In: Rowman \& Littlefield pub Inc

Shy $O$ and Tarkka J (1998). The market for electronic cash cards. Research Discussion Paper 21/1998, Bank of Finland. https://helda.helsinki.fi/bof/bitstream/handle/123456789/7682/87446.pdf. Accessed 1 Jan 2018

White LH (1986) Competitive payments systems: reply. Am Econ Rev 76(4):850-853

White LH (1984a) Competitive payments systems and the unit of account. Am Econ Rev 74(4):699-712

White LH (1984b) Free banking in Britain: theory, experience, and debate, 1800-1845. Cambridge University Press, New York

\section{Submit your manuscript to a SpringerOpen ${ }^{\bullet}$ journal and benefit from:}

- Convenient online submission

- Rigorous peer review

Open access: articles freely available online

- High visibility within the field

- Retaining the copyright to your article

Submit your next manuscript at $\boldsymbol{s p r i n g e r o p e n . c o m ~}$ 